\title{
Systematics and relationships of Tryssophyton (Melastomataceae), with a second species from the Pakaraima Mountains of Guyana
}

\author{
Kenneth J. Wurdack', Fabián A. Michelangeli² \\ I Department of Botany, MRC-166 National Museum of Natural History, Smithsonian Institution, P.O. Box \\ 37012, Washington, DC 20013-7012, USA 2 The New York Botanical Garden, 2900 Southern Blvd., Bronx, \\ NY 10458, USA
}

Corresponding author: Kenneth J. Wurdack (wurdackk@si.edu)

Academic editor: Ricardo Kriebel | Received 25 July 2019 | Accepted 30 October 2019 | Published 10 December 2019

Citation: Wurdack KJ, Michelangeli FA (2019) Systematics and relationships of Tryssophyton (Melastomataceae), with a second species from the Pakaraima Mountains of Guyana. PhytoKeys 136: 1-21. https://doi.org/10.3897/ phytokeys. 136.38558

\begin{abstract}
The systematics of Tryssophyton, herbs endemic to the Pakaraima Mountains of western Guyana, is reviewed and Tryssophyton quadrifolius K.Wurdack \& Michelang., sp. nov. from the summit of Kamakusa Mountain is described as the second species in the genus. The new species is distinguished from its closest relative, Tryssophyton merumense, by striking vegetative differences, including number of leaves per stem and leaf architecture. A phylogenetic analysis of sequence data from three plastid loci and Melastomataceae-wide taxon sampling is presented. The two species of Tryssophyton are recovered as monophyletic and associated with mostly Old World tribe Sonerileae. Fruit, seed and leaf morphology are described for the first time, biogeography is discussed and both species are illustrated.
\end{abstract}

\section{Keywords}

Guyana, leaf anatomy, Melastomataceae, molecular phylogeny, seeds, Sonerileae

\section{Introduction}

The flora of Guyana contains about 290 taxa of Melastomataceae in 40 genera, including three small endemic genera, Maguireanthus Wurdack, Ochthephilus Wurdack and Tryssophyton Wurdack (Wurdack 1993, Funk et al. 2007). These endemics are poorly known herbs from wet slope-forests in the Pakaraima Mountains, a region that is rich 
in Guiana Shield biota. Boyania Wurdack had been an additional Pakaraima Mountains endemic genus, based on B. ayangannae Wurdack, until a second species (B. colombiana Humberto Mend.) was unexpectedly discovered in Colombia (Mendoza-Cifuentes 2010). Tryssophyton was described in 1964 by John Wurdack as a very distinct monotypic genus that he assigned to tribe Bertolonieae. As a small, rhizomatous herb with a single stem crowned by a cluster of 10-16 narrow leaves, it vegetatively presents an atypical melastome, even amongst the highly variable, mostly herbaceous Bertolonieae. However, Bertolonieae, as traditionally circumscribed (i.e. sensu lato), has been shown to be polyphyletic with genera formerly assigned to it resolved within the Merianieae and two other distinct clades (Michelangeli et al. 2011, Goldenberg et al. 2015). The tribe has been recently narrowly circumscribed to contain only Bertolonia Raddi (Bacci et al. 2019).

Tryssophyton has been little studied since its description and collections have remained few. A 2012 expedition in the Pakaraima Mountains to reach the botanically unexplored ca. $1700 \mathrm{~m}$ summit of Kamakusa Mountain yielded new collections of the type species, T. merumense Wurdack, at lower elevations and a novel new species at the summit, which is described herein. We also provide further observations on the morphology and relationships of both species. Kamakusa Mountain and its vicinity at the wet, eastern edge of the Pakaraima Mountains have yielded many new plant taxa from the two expeditions $(1960,2012)$ that have traversed this remote region and it deserves further scientific exploration (Wurdack et al. 2013, Wurdack 2017).

\section{Materials and methods}

In order to ascertain the phylogenetic position of both species of Tryssophyton, we sequenced plastid $r b c L$ and/or $n d h F$ following protocols and primers used in previous broad studies of the Melastomataceae (i.e. Clausing and Renner 2001, Michelangeli et al. 2011, 2014, Goldenberg et al. 2012, 2015). These data were analysed in the context of a family-wide taxon sampling for three plastid loci, $n d h F, r b c L$ and $r p l 16$ (last locus treated as missing data for Tryssophyton) that included six representatives of other families of Myrtales as outgroups (see Appendix 1). All other sequences were obtained from GenBank (https://www.ncbi.nlm.nih.gov/genbank/) and mostly published in previous studies (Clausing and Renner 2001, Michelangeli et al. 2011, 2014, Goldenberg et al. 2012, 2015, Zeng et al. 2016), although a few have not been previously cited. Contigs were assembled in Geneious ver. 11 (http://www.geneious.com, Kearse et al. 2012) and alignments were performed with MUSCLE (Edgar 2004) as implemented through the Geneious plugin with the following parameters: maximum trees to build 20, optimal and diagonal optimisations on, anchor spacing 32 and minimum length of 24 . The loci were analysed separately for quality control and then as a concatenated 3-locus analysis with no character exclusion sets. A maximum likelihood (ML) analysis was performed with RAxML ver. 8 (Stamatakis 2014) as implemented on CIPRES XSEDE (https:// www.phylo.org/) with each locus as a separate partition. Clade support was estimated by bootstrap percentages (BP) using the same search conditions on $1000 \mathrm{ML}$ replicates. 
Scanning electron microscopy (SEM) used a Zeiss EVO MA15 (Carl Zeiss SMT, Inc., Peabody, Massachusetts) at 6-12 kV after sputter-coating herbarium specimen seeds or critical point dried (CPD) field-fixed (in ethanol) leaves with $25 \mathrm{~nm}$ of C + Au/Pd using a Leica EM ACE600 (Leica Microsystems GmbH, Wetzlar, Germany). Leaves were examined for venation after clearing in ethanol or $2.5 \%$ sodium hydroxide. For internal structure, they were hand cut for SEM or, for light microscopy (LM), they were paraffin-embedded, sectioned at $10 \mu \mathrm{m}$, stained with toluidine blue $\mathrm{O}$ and examined with a Zeiss Universal Compound Microscope. The anatomy of the delicate leaves was more intact with CPD and SEM than after traditional thin sectioning from the same starting material, thus our observations are largely based on SEM.

\section{Phylogenetic results}

Melastomataceae are resolved as a strongly supported (BP 100) family with mixed backbone support, which of relevance here was notably weak (BP 60 or less) amongst the deepest nodes of Sonerileae (Fig. 1). Both species of Tryssophyton form a strongly supported clade (BP 93) that is weakly resolved (BP 65) with African Calvoa near the base of the Sonerileae-Dissochaeteae complex (sensu Renner et al. 2001). Boyania is weakly supported (BP 60) as the earliest diverging member of Sonerileae. Marcetieae are sister to Melastomateae and distant from Tryssophyton.

\section{Taxonomic treatment}

\section{Tryssophyton quadrifolius K.Wurdack \& Michelang., sp. nov.} urn:lsid:ipni.org:names:77203430-1

Figure 2

Diagnosis. Differs from Tryssophyton merumense in 4-verticillate, ovate, petiolate leaves, versus 10-16 verticillate, oblanceolate-lanceolate, subsessile leaves.

Type. Guyana. Cuyuni-Mazaruni Region: Summit of Kamakusa Mtn. (i.e. on top of $4^{\text {th }}$ escarpment of four); impenetrable elfin forest to $3 \mathrm{~m}$, extremely dense and wet, rich in epiphytes, with Bonnetia (2 spp.), Brocchinia cf. tatei, Malpighiaceae, Melastomataceae, Cyperaceae spp., Weinmannia, Ilex cf. retusa, 5'52'50.9"N, 606'11.7"W, 1691 m elev., 8 June 2012 (fl.), K. Wurdack 5865 with E. Tripp, A. Radosavljevic, and J. Ralph (holotype: BRG!, isotype: US-3731242!).

Description. Habit perennial, rhizomatous herbs; rhizomes persistent, fleshy, horizontal, to $10 \mathrm{~cm}$ long, 3-6 $\mathrm{mm}$ diam., rarely branched, bearing 1-2 leafy, erect, aerial stems per axis and older cup-shaped (collar to $0.3 \mathrm{~mm}$ high and centre sunken) aerial stem scars; adventitious roots fine, fibrous. Indument sparse on aerial stems, leaves, pedicels, hypanthium and sepal margins; trichomes simple, to $0.1 \mathrm{~mm}$ long, glandular, reddish. Aerial stems $8.5-11.5 \mathrm{~cm}$ tall, $0.9-2 \mathrm{~mm}$ diam., terete, purple, slightly flared 


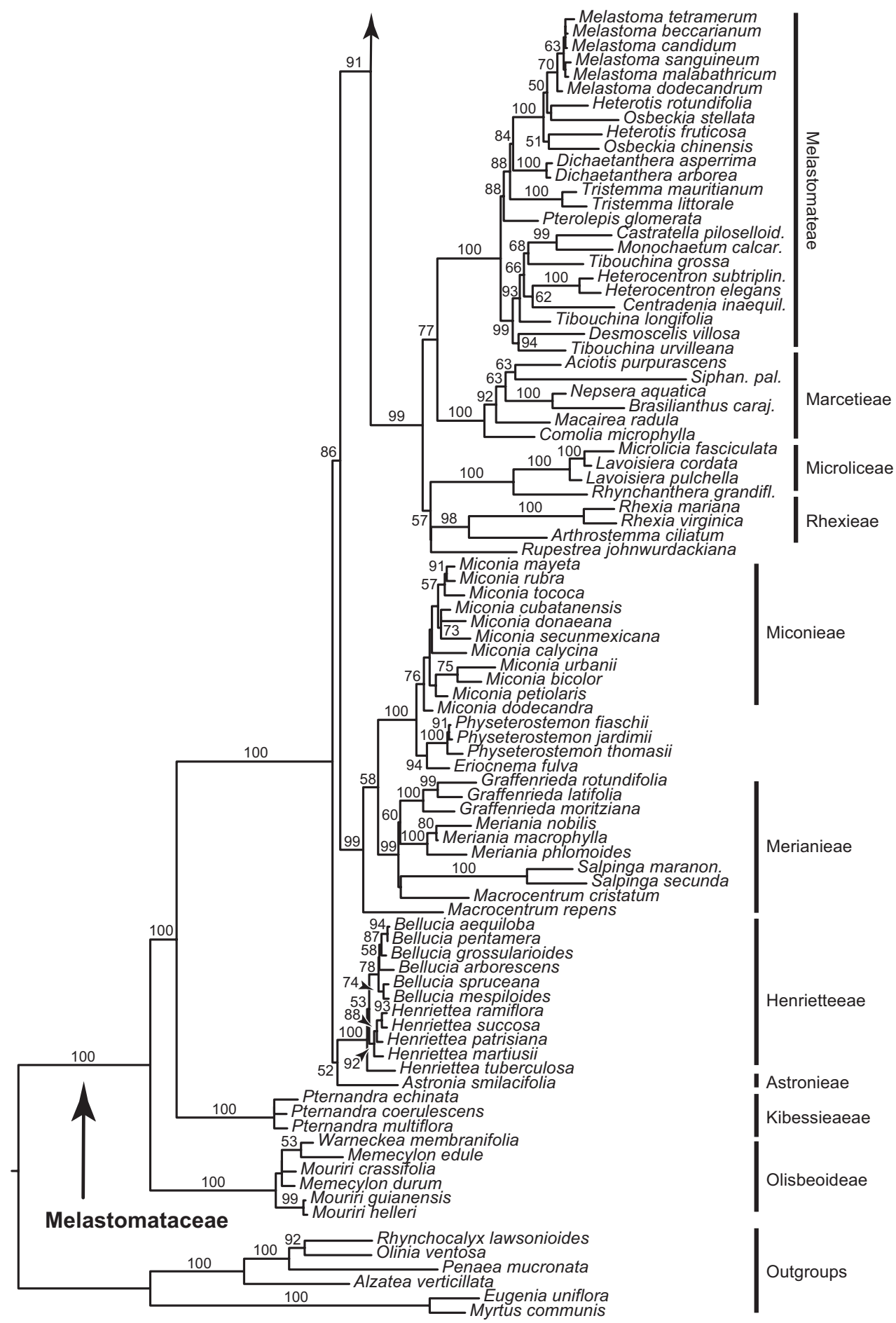

Figure I. Relationships of Tryssophyton in a 3-locus phylogeny of Melastomataceae. Maximum likelihood tree with bootstrap support values based on analysis of plastid $n d h F, r b c L$ and $r p l 16$ data. 


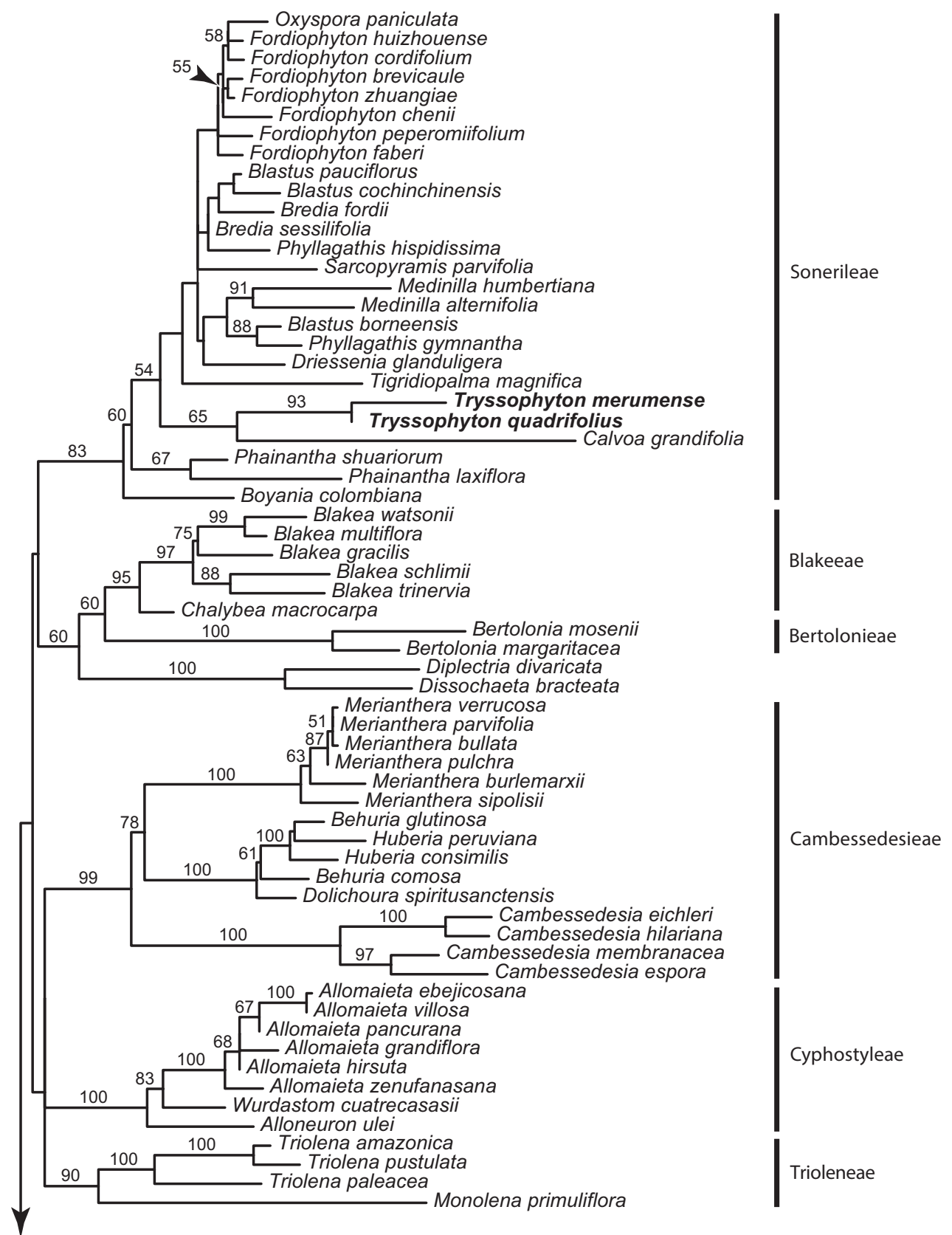

Figure I. Continued. 
at rhizome attachment, summit with cluster of leaves and often 1 secondary branch 1-2 cm long and crowned by another cluster of leaves. Leaves 4-verticillate, opposite pairs sub-equal in size, simple, petiolate, exstipulate; petioles $2-5 \mathrm{~mm}$ long (of slightly subequal length within whorl), ca. $1 \mathrm{~mm}$ diam.; lamina $2.1-5.2 \times 1.0-1.9 \mathrm{~cm}$, length:width ratio $2.2-3.7: 1$ (mean $=3.0, \mathrm{SD}=0.50, n=11$ ), symmetrical, ovate to lanceolate, membranous, apex acuminate, base cuneate, margin minutely serrate, with 6-12 teeth per side $(2-5$ teeth $/ \mathrm{cm})$; teeth $0.5-0.9 \times 0.1 \mathrm{~mm}$, first-order, spacing regular, projecting $0.2-0.3 \mathrm{~mm}$ from margin, sinus shape rounded, distal flank concave and proximal flank straight, apex long-attenuate; leaf tip with 1-3(13) adaxial scales, 0.6-1 $\times 0.1 \mathrm{~mm}$, similar to attenuate teeth apices. Venation suprabasal acrodromous, with one pair of major (costal) secondaries $1 / 2$ of the gauge of the midvein, joining the midvein $0.5-1 \mathrm{~mm}$ above the leaf base; and one pair of intramarginal secondaries $<1 / 3$ of the gauge of the midvein (poorly defined from tertiary thickness), joining $<0.5 \mathrm{~mm}$ from base, traversing $0.2-0.8 \mathrm{~mm}$ from margin, distally fading into exterior tertiary loops; up to 12 interior tertiary veins per side, quaternaries random reticulate. Inflorescence terminal, pedunculate, bearing 1-4 flowers; peduncle $2.2-2.6 \mathrm{~cm}$ long, $0.5-0.7 \mathrm{~mm}$ diam. mid-length, terete, flaring at base, purple; bracts persistent, lanceolate, 1-1.3 $\times$ 0.3-0.4 mm, apex apiculate, margin entire. Flowers 4-merous, bisexual, pedicellate; pedicels $8.5-11.5 \mathrm{~mm}$ long, $0.4-0.6 \mathrm{~mm}$ diam. mid-length, terete, purple; hypanthium at anthesis ca. $2.5 \mathrm{~mm} \times 2-2.5 \mathrm{~mm}$ (excluding calyx), campanulate, obscurely costate with thin ribs; calyx lobes 4 , in bud narrowly triangular, ascending, protective of young corolla, at anthesis spreading, $0.8-1 \mathrm{~mm}$ tall, broadly triangular above short calyx tube ca. $0.4 \mathrm{~mm}$ high; petals ca. $9.5 \times 5 \mathrm{~mm}$, margins entire, in vivo red outside and pink inside. Stamens 8 , incurved in bud with tips extending into hypanthium below point of filament attachment, slightly anisomorphic, with the antesepalous whorl larger than the antepetalous, glabrous; filaments 5-6 (antesepalous) or 4 (antepetalous) mm long, $0.2 \mathrm{~mm}$ diam., linear, pink in vivo; thecae 4.5 or $3.5 \mathrm{~mm}$ long, basifixed, connective basally prolonged, dilated below thecae, forming a thickened annulus that is more or less ventrally bilobate, thickening 0.8 or $0.5-0.6 \mathrm{~mm}$ diam., yellow in vivo; anther $0.1-0.2 \mathrm{~mm}$ wide at terminal pore. Ovary superior, ca. $1.8 \times 1.3-1.5 \mathrm{~mm}$, glabrous. Style ca. $10 \mathrm{~mm}$ long, $0.2 \mathrm{~mm}$ diam., curved, glabrous; stigma punctiform, minutely papillose. Capsule ovate, ca. $3 \times 3.5 \mathrm{~mm}$, crowned by persistent calyx. Seeds ovoid, ca. $0.7 \times 0.4 \mathrm{~mm}$ (immature and partly collapsed), sparsely papillose, brown.

Etymology. The specific epithet is derived from quadri- (Latin, four) and folium (Latin, leaf) and refers to the 4-verticillate leaves.

Distribution and ecology. Tryssophyton quadrifolius is only known from the summit of Kamakusa Mountain where it was encountered as an infrequent epiphyte on moss and lichen covered branches and trunks of large shrubs. Scattered small plants with single stems were observed sporadically along the main trail transect cut along the north-south orientated narrow summit. The few reproductive plants were in a more sheltered spot on the western edge of the summit on a branch trail that was cut to a cliff edge for a view. Flowers and young fruit were collected in June. The summit of Kamakusa Mountain is covered by low montane evergreen cloud forest, $3-4 \mathrm{~m}$ tall, with 


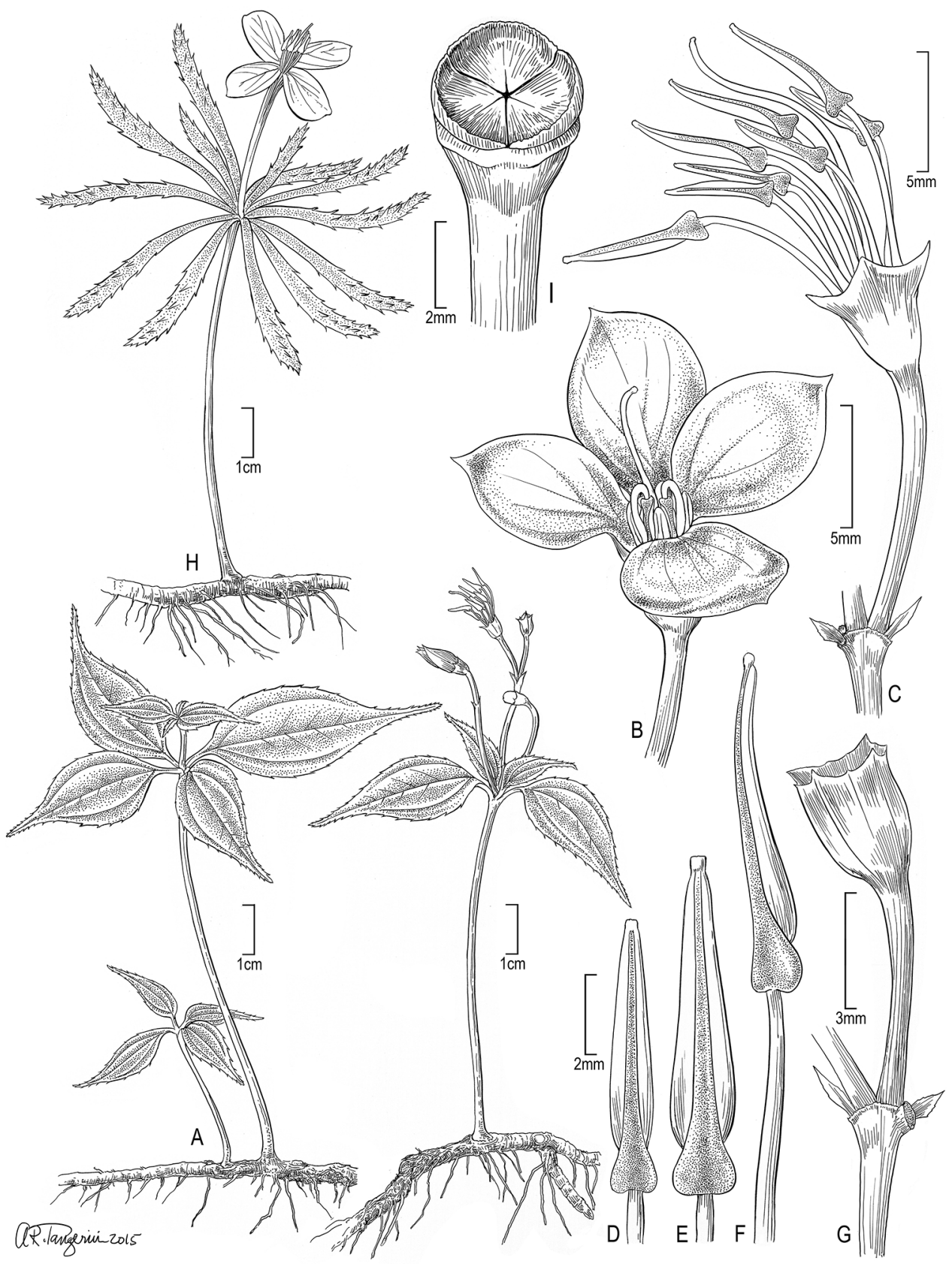

Figure 2. Illustration of Tryssophyton quadrifolius $(\mathbf{A}-\mathbf{G})$ and T. merumense $(\mathbf{H}, \mathbf{I})$. A Habit (right view in flower) B young flower with anthers inflexed $\mathbf{C}$ flower with anthers erect and petals fallen $\mathbf{D}$ shorter antepetalous anther, dorsal $\mathbf{E}$ longer antesepalous anther, dorsal $\mathbf{F}$ longer anther, lateral $\mathbf{G}$ young fruit $\mathbf{H}$ habit I capsular, 3-merous fruit. Sources: A-G Wurdack 5865 H Radosavljevic 165 I Wurdack 5870 (all US). 
dense thickets dominated by Bonnetia tepuiensis Kobuski \& Steyerm. and B. roraimae Oliv. (Bonnetiaceae), Byrsonima pachypoda W.R. Anderson (Malpighiaceae), Miconia acutifolia Ule and M. silicicola Gleason (Melastomataceae), Raveniopsis microphyllus $\mathrm{K}$. Wurdack (Rutaceae) and species of Weinmannia L. (Cunoniaceae) on a peat substrate overlying sandstone. Vascular epiphytes included species of Utricularia L. (Lentibulariaceae), Bromeliaceae and Orchidaceae.

Conservation status. While the upper part of Kamakusa Mountain is presently pristine and undisturbed, the new species is a delicate epiphytic herb with few reproductive plants ( 2 of 15 aerial stems collected had buds, flowers and/or fruit) in an area of extremely limited montane habitat. The species is vulnerable to climate and land use changes, such as regional gold mining (see Wurdack 2017). Following the criteria and categories of IUCN $(2012,2019)$ and similar to the recently described Kamakusa endemic Raveniopsis microphyllus, Tryssophyton quadrifolius is given a preliminary status of Critically Endangered (CR) under geographic range criteria B1 (extent of occurrence $<100 \mathrm{~km}^{2}$ (B1) and area of occupancy $<10 \mathrm{~km}^{2}$ (B2a, number of locations =1; $\mathrm{B} 2 \mathrm{~b}$, continuing decline projected).

\section{Tryssophyton merumense Wurdack, Mem. New York Bot. Gard. 10: 155.1964.}

Type. Guyana. Cuyuni-Mazaruni Region, Partang River, Merume Mtns., Merume Mt.; common on mossy logs in forest, 1140 m elev., 4 Jul 1960 (fl., fr.), S.S. Tillett, C.L. Tillett, \& R. Boyan 43988 (holotype: US-2343844!; isotypes: K-000329332!, NY-00245868!).

It should be noted that both the US and NY sheets are each marked as the holotype. However, the protologue clearly states that the US specimen is the holotype, even citing the sheet number and has that designation in J. Wurdack's handwriting. The NY sheet has "holotype" merely typed on the label. Thus, there is no need to lectotypify this name and the NY specimen should be considered as an isotype.

Etymology. The genus is combined from tryssos (Greek, dainty or delicate) and phyton (Greek, plant) and refers to the plant habit. The specific epithet refers to Merume Mountain where the type was collected.

Additional collections examined. GUYANA. Cuyuni-Mazaruni Region: Pakaraima Mountains, upper Karowrieng River at Maipuri Falls; mixed bryophyte, pteridophyte, herb community; sandstone boulders, white sand, large cave behind falls, $5^{\circ} 41^{\prime} \mathrm{N}$, 60 $13^{\prime} \mathrm{W}, 575-600 \mathrm{~m}$ elev., 13 Oct 1992 (fl.), B. Hoffmann 2939 (NY!, US!). $2^{\text {nd }}$ and $3^{\text {rd }}$ escarpments (of four) of Kamakusa Mt., upper west-facing slopes below summit, rich forest with Licania, Ebenaceae, tree ferns, Arecaceae, 5'52'55.2"N, 606 $34.5^{\prime \prime} \mathrm{W}$, 1330 m elev., 8 June 2012 (fl., fr.), K. Wurdack 5870 (US!). Potaro-Siparuni Region: Mt. Wokomung, easternmost pinnacle of massif, scrub forest on sandstone and peat, with Guadua, Euterpe, and Sphagnum, 5०5'34.4"N, 59 50'13.3"W, 1524 m elev., 13 Jul 2003 (fl.), H.D. Clarke 10822 (NY!, US!). Mt. Ayanganna, east slope, plateau above second escarpment, growing on mossy tree trunks and roots, $5^{\circ} 22^{\prime} 28^{\prime \prime N}, 59^{\circ} 58^{\prime} 06^{\prime \prime} \mathrm{W}$, 1340 m elev., 16 Mar 2014 (f.), A. Radosavljevic 165 (US!). 
Distribution and ecology. The five collections of T. merumense span a $90 \mathrm{~km} \mathrm{sec-}$ tion of the central Pakaraima Mountains, but further exploration is likely to expand its range into similar habitats. The species was only recently discovered (Radosavljevic 165) on the slopes of relatively well-explored Mount Ayanganna, the highest mountain (2041 m) wholly within Guyana. At mid-elevations on the western slopes of Kamakusa Mountain, it occurred (Wurdack 5870) as scattered, rarely-reproductive individuals on rotting logs and peaty-humus zones around the bases of trees.

The mountainous area north of the village of Imbaimadai and including Kamakusa Mountain has been variously mapped as the Merume Mountains. However, exactly what corresponds to the peak "Merume Mountain" within the region and indicated as the type locality of T. merumense, is unclear. Field notes (Bassett Maguire Field Collections, vol. 19, Archives of The New York Botanical Garden) reveal that during 11 Jun-16 Jul 1960, after leaving Imbaimadai, the collecting team, led by Stephen Tillett entered the Kamakusa Mountain area from along the Partang River. After reaching Partang Falls, they ascended into the uplands following existing trails, which were probably made by gold-miners or "pork-knockers." It is likely that "Merume Mountain" of Tillett et al. is equivalent to Kamakusa Mountain, but details referring to lower elevations, southeast ridge, southeast side and cliffs do not indicate they reached summit where T. quadrifolius was collected.

\section{Discussion}

The broader relationships which we recovered within Melastomataceae largely agree with those from prior studies using the underlying sequence data (i.e. Clausing and Renner 2001, Michelangeli et al. 2011, 2014, Goldenberg et al. 2012, 2015, Zeng et al. 2016, Bacci et al. 2019). Tryssophyton is clearly monophyletic and a member of the Sonerileae-Dissochateae complex, although a sister-relationship with Calvoa Hook. f. has low support and resolution within the tribe is also poor. A weaker $(\mathrm{BP}<50)$ placement with Calvoa was recently reported for T. merumense, based on ITS data (Bacci et al. 2019). Calvoa is a tropical African genus containing about 19 species of herbs to small, woody shrubs (Jacques-Félix 1981, Figueiredo 2001). Calvoa has funnelform and costate hypanthia that develop into apically dehiscent capsules and are features common to most genera that have been assigned to the Bertolonieae + Sonerileae (Renner 1993, Bacci et al. 2019). However, the staminal morphology of Calvoa with short pedoconnectives and dorsal appendages (Jacques-Félix 1981) does not resemble that of Tryssophyton. Sarcopyramis Wall. (not sampled here; see Bacci et al. 2019), a southeast Asian genus of one morphologically variable (S. napalensis Wall., sensu lato; Hansen 1978) or multiple species of herbs was found by Bacci et al. (2019) to also belong to this clade and is similar to Calvoa in details of stamen morphology and long-papillose stigmas.

The more robust placement of Tryssophyton within Sonerileae has clearer implications for taxonomy and historical biogeography. When originally describing Tryssophyton, J. Wurdack (1964) placed it in Bertolonieae, presumably based on its herbaceous habit and 
fruit morphology, but he also compared it to Asian and African members of the Sonerileae as possible relatives. Bertolonieae has been shown as widely polyphyletic (Bacci et al. 2019). Wurdack (1964) also compared the stamens of Tryssophyton to those of Marcetia DC., due to their elongated shape and lack of pedoconnectives or appendages. Marcetia (not sampled here but clearly affiliated with other genera included in the Marcetieae; see Rocha et al. 2016, 2018) is not related to Tryssophyton and its seed morphology is markedly different in being cochleate and large-tuberculate (Rocha et al. 2018: fig. 7T).

The great majority of the species in the Sonerileae-Dissochaeteae complex are found in the Old World. The exceptions are Tryssophyton and the Neotropical genera Boyania and Phainantha, resolved as successive branches, with poor support, at the base of the clade. Boyania contains two trailing (stoloniferous) or climbing herbaceous species with disjunct distributions. One of them, Boyania ayangannae, also grows in the same region as Tryssophyton, while the second species, Boyania colombiana, is restricted to the easternmost slopes of the Colombian Andes (Mendoza-Cifuentes 2010). Boyania was also initially placed in the Bertolonieae, based on habit and fruit and anther morphology, but J. Wurdack remarked that, given its 5-locular ovaries, it was intermediate between New World Bertolonieae and Old World Sonerileae. Recent phylogenetic evidence has suggested that Boyania may not be monophyletic (Bacci et al. 2019), although both species are morphologically similar. Phainantha contains five mostly climbing woody species (trailing herb in P. steyermarkii Wurdack), four of which are found in the Guiana Shield and one in southern Ecuador from the Cordillera del Condor which has phytogeographic ties with the Guiana Shield (Wurdack 1993, Berry et al. 2001, Ulloa Ulloa and Neill 2006). Phainantha was initially unplaced when described by Gleason (1948) due to lack of seeds and subsequently Renner (1993) placed it with Merianieae in her family-wide morphological analysis of the Melastomataceae. The character evolution and biogeography implications with the resolution of these three neotropical genera at or near the base of the Sonerileae-Dissochaeteae complex are important for understanding the evolution of the entire clade. For example, there are notable differences in merosity; Phainantha, Sarcopyramis and Tryssophyton are 4-merous and Boyania and Calvoa are 5-merous. The support for the early-diverging nodes of this clade is presently poor and the taxonomic and geographical sampling is too small for firm conclusions. However, if this topology holds with increased sampling of taxa and genetic loci, it would suggest that the mostly Asian Sonerileae-Dissochaeteae complex originated in South America and then dispersed to Africa and later to Asia where it diversified. A similar pattern has been found to the Melastomateae (Michelangeli et al. 2013, Veranso-Libalah et al. 2017). Recent phylogenetic studies of the Sonerileae-Dissochaeteae complex have already shown that most genera are not monophyletic and the group needs considerable further study (Zeng et al. 2016, Zhou et al. 2019a, 2019b).

\section{Morphology of Tryssophyton}

Although reproductive features (flowers and fruit) and overall habit (rhizomatous herbs) are nearly identical between the two species, Tryssophyton quadrifolius is vegetatively 
easily distinguished by fewer leaves per stem and differences in leaf architecture (see Diagnosis; Figs 2, 3). Both species have short stems $(6.5-11.5 \mathrm{~cm}$ tall), which are each crowned with a cluster of leaves; they sometimes possess additional leaf sets topping 1-5 shorter $(1.5-3.5 \mathrm{~cm}$ tall) secondary branches arising from the first crown. This pattern of reiteration with secondary branches crowned by leaves has not been previously reported for T. merumense; it is not seen on the holotype but occurs on some plants in all other collections. In T. quadrifolius, each leaf cluster is comprised of two decussate pairs of opposite leaves that are nearly superposed so as to appear 4-verticillate. In T. merumense, the 10-16 leaves of varying sizes form a tight verticillate-like cluster and is likely a spiral decussate arrangement of multiple, nearly superposed leaf pairs. The rows (parastichies) of leaf attachment scars apparently form genetic spirals (Fig. $3 \mathrm{~K}$ ) and self-shading is largely absent (Fig. 3A, B). Tryssophyton quadrifolius resembles a typical melastome with regard to leaf form while T. merumense deviates with its narrow leaves, which have juvenile aspects of young leaves before full expansion. The leaves of $T$. merumense have been described as sessile (Wurdack 1964, 1993). The laminar base is finely tapering (attenuate) and decurrent, obscuring any defined petiole which is in marked contrast with T. quadrifolius where the petiole is well defined from the cuneate base. The venation of T. quadrifolius is suprabasal acrodromous with two sets of lateral major veins including a pair of costal secondaries diverging clearly above the leaf base and a pair of thinner intramarginal secondaries diverging closer to the base (Fig. 3E). It has well-developed higher order veins including tertiaries connecting the major veins and a ramified quaternary vein network and has simple teeth partly penetrated by a thickened principal vein (Fig. 3F). The venation of T. merumense is acrodromous with only a single pair of lateral major veins that traverse the attenuate leaf base (i.e. not suprabasal) through the length of the leaf and sparse higher order veins (Fig. 3H). The teeth (Fig. 3I, J) are similar, but shorter and the thickening of their principal vein is more pronounced than in T. quadrifolius. Boyania, Calvoa and Sarcopyramis usually have two pairs of lateral major veins (prominent costal and thinner intramarginal secondaries) that begin at the leaf base. Phainantha is more diverse with variation in costal secondary vein position relative to the margin and often well-developed intramarginal veins. In Phainantha shuariorum C. Ulloa \& D.A. Neill (Palacios et al. 8565, US), the costal veins are so close to the margins so as to appear nearly marginal; however a narrow pair of intramarginal veins remains along the lower edges before distally merging with the adjacent costal veins.

While both Tryssophyton species grow on Kamakusa Mountain, they do not appear to be sympatric (K. Wurdack, personal observation) and their local habitats differ in elevation, exposure and vegetation type. Tryssophyton quadrifolius would appear poorly adapted from an ecophysiology perspective as a summit endemic, with relatively large thin leaves, compared with much of the associated montane vegetation which has reduced sclerophyllous and/or coriaceous physiognomies as adaptations to cold and exposure (see Wurdack 2017). It is fundamentally terrestrial in nature with very similar rhizome and root morphologies to T. merumense and the observed epiphytism is likely opportunistic (i.e. a facultative epiphyte) in a very wet, dense-shrub habitat with sparse herbaceous understorey. The delicate leaf of $T$. merumense in transverse view shows dorsiventral differentiation and consists of a lamina up to six layers thick, organised as a 

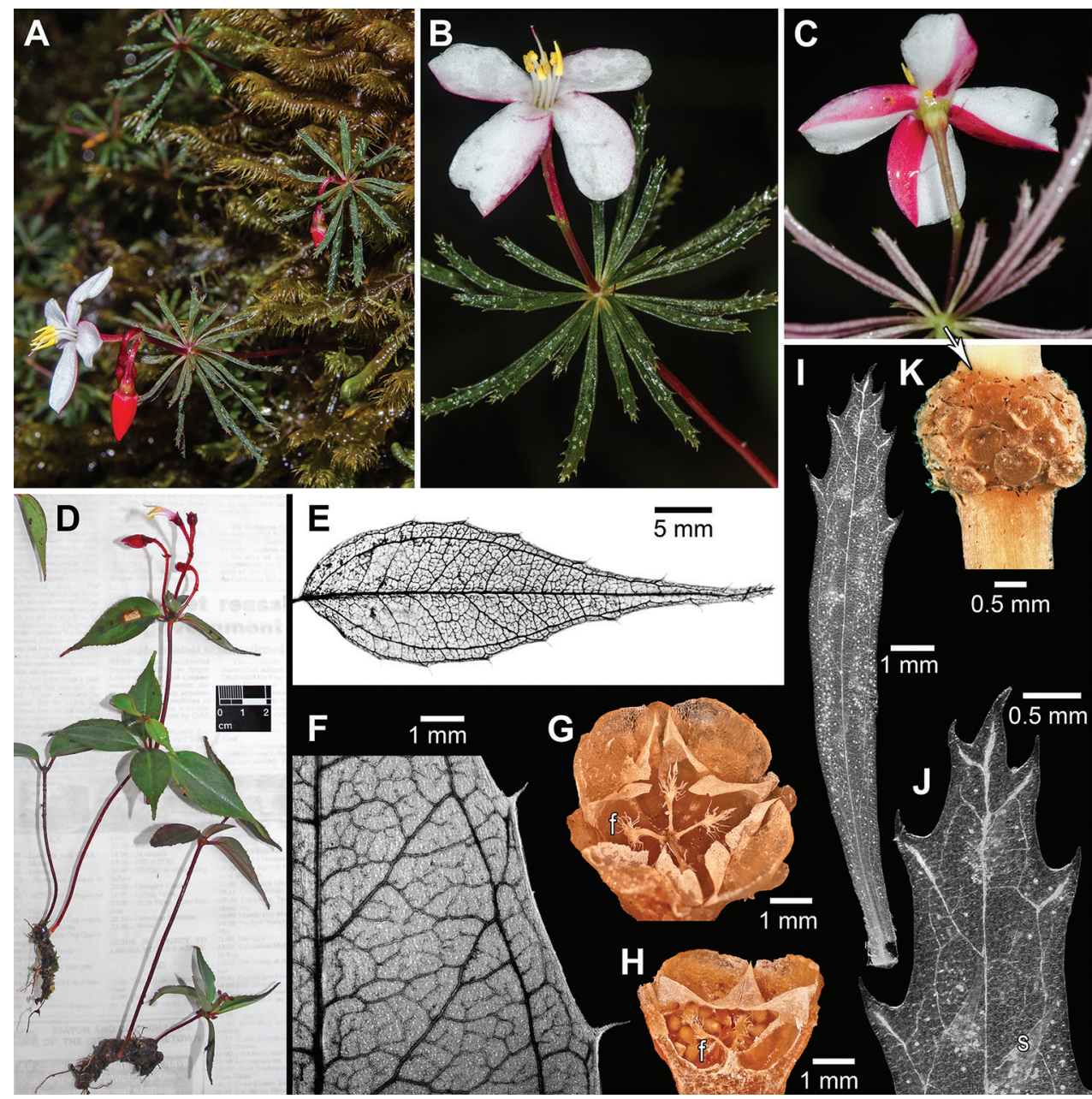

Figure 3. Macromorphology of Tryssophyton merumense (A-C, G-K) and T. quadrifolius (D-F). A habit, growing with bryophytes and downward pointing red buds B flowering plant, adaxial C Flowering plant showing bicoloured petals, abaxial $\mathbf{D}$ part of type collection in vivo just before pressing $\mathbf{E}$ whole leaf venation, abaxial $\mathbf{F}$ venation close-up showing major veins and reticulate quaternaries, abaxial $\mathbf{G}$ Dehisced 4-merous fruit, with interior persistent fimbriate placenta remnants (f), axial (tips of 8 triangular valves partly broken) $\mathbf{H}$ fruit, with seeds, fimbriae (f) and carpel septa, transverse view I whole leaf venation and crystal druses (white spots), adaxial J close-up of leaf tip with marginal teeth and non-vascularised scales (s), adaxial $\mathbf{K}$ phyllotactic arrangement with leaf attachment scars surrounded by darkened glandular trichomes, lateral view with main stem at bottom, peduncle at top. Sources: A-C, I-K Radosavljevic 165 D-F Wurdack 5865 G, H Wurdack 5870 (all US).

single epidermal layer of thin-walled cells lacking thickened cuticles (adaxial epidermal layer of larger cells than the abaxial layer), a single layer of elongate tapered palisade parenchyma cells, rich in plastids and having considerable intercellular space towards their abaxial ends and a spongy parenchyma layer 2-3 cells thick (Fig. 4C, F). Sto- 


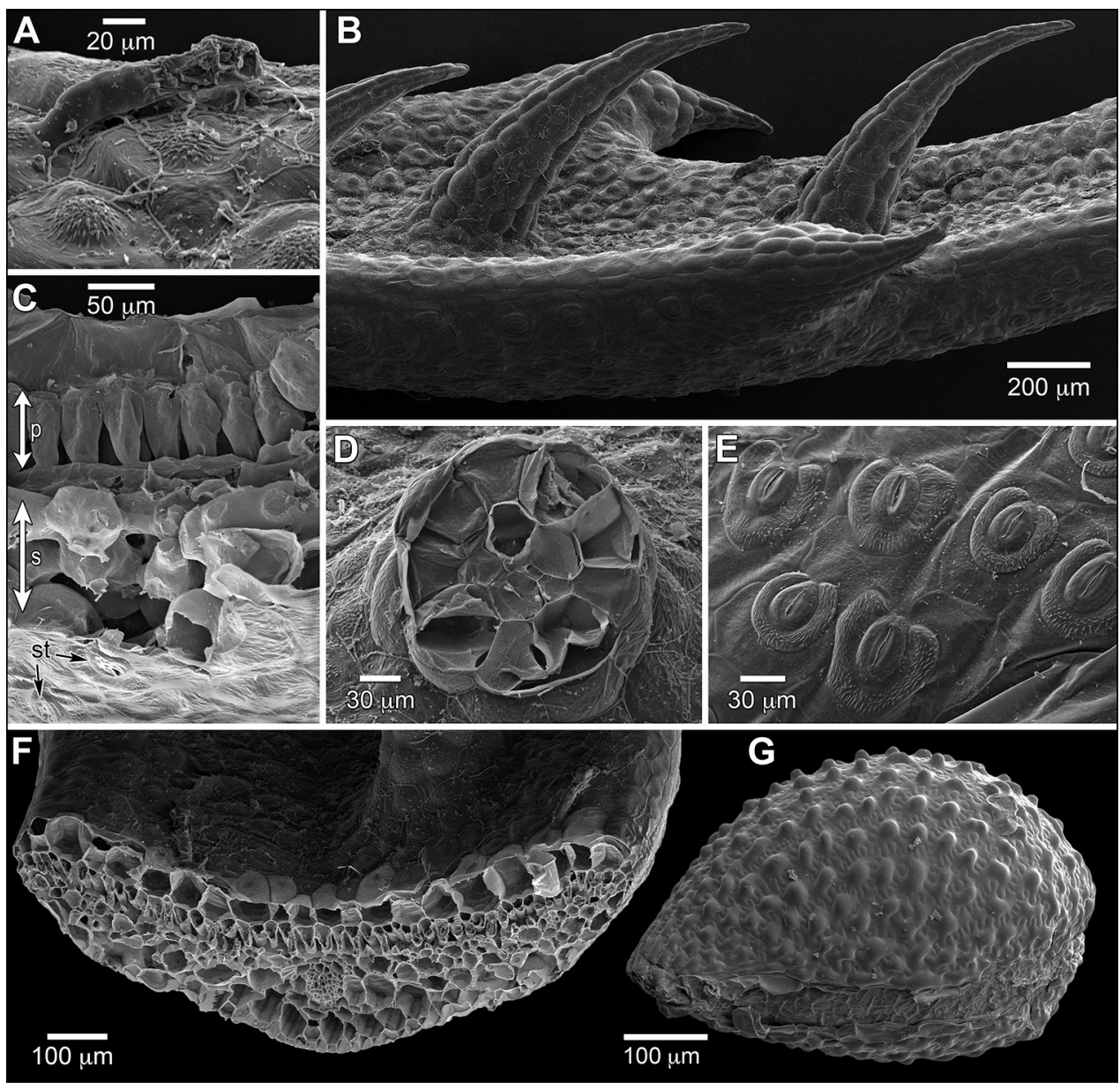

Figure 4. Micromorphology of Tryssophyton merumense. A Leaf glandular trichome, adaxial B leaf with marginal teeth, erect adaxial scales and glandular trichomes, lateral view of distal part $\mathbf{C}$ leaf, with single file palisade parenchyma (p), loose spongy parenchyma ( $s$ ) and stomata (st) beneath intercellular spaces, close-up of transverse view D leaf scale, transverse view near adaxial scale base $\mathbf{E}$ stomata, abaxial $\mathbf{F}$ leaf, transverse view $\mathbf{G}$ seed, lateral view with raphal zone near bottom. Sources: A-F Radosavljevic 165 G Wurdack 5870 (all US).

mata of the paracytic type are confined to the relatively smooth abaxial side (Fig. 4E) and large crystal druses occur occasionally in the mesophyll. The leaf ornamentation consists of short-stalked glandular trichomes (sensu classification of Wurdack [1986], but not surveyed there; Fig. 4A) and sparse adaxial scales ("sparsely strigulose," according to Wurdack 1964, 1993), resembling erect horns that are typically collapsed in herbarium specimens (Fig. 4B, not collapsed due to CPD). These scales are $0.3-1$ by $0.2 \mathrm{~mm}$ in size, loosely arranged in two files parallel to the midvein, multicellular, non-vascularised and have a rosette-like base of two undifferentiated cell layers (Figs 3J, 4B, D). While the scales and marginal teeth are superficially similar in form, 
the slightly shorter, fatter teeth terminate principal veins that traverse halfway into the tooth (i.e. submarginal principal vein termination; Figs 3J, 4B). The thin leaves of T. quadrifolius were not examined in transverse view, but clearly possess many of the same features including paracytic stomata and crystal druses; surface ornamentation is similar but the scales are slightly larger and only occur sparsely at the leaf tip. The teeth apices are also more prolonged in T. quadrifolius $(0.5-0.9 \mathrm{~mm}$ long) than T. merumense $(0.2-0.3[0.4] \mathrm{mm})$. Species of Boyania, Calvoa and Phainantha variously have similar glandular trichomes along with long simple trichomes, but not the scales. In addition, other taxa formerly placed in the Bertolonieae (e.g. Salpinga peruviana [Cogn.] Wurdack and Sarcopyramis napalensis Wall.) have glandular trichomes and/or scales.

Amongst reproductive features, the buds of both Tryssophyton species are red due to a pigmented layer of the outer (abaxial) exposed parts of the petals, which then open to reveal lighter inner surfaces. Tryssophyton merumense has white inner (adaxial) petal surfaces and filaments, leaving the exterior strikingly bicoloured where the petals overlapped in bud (giving them a distinctive "candy-cane" pattern) and were still evident on the holotype (Fig. 3A-C). Tryssophyton quadrifolius differs slightly in floral colour with petals that are pink on the adaxial surfaces and pink filaments (Fig. 3D). The fruits and seeds of Tryssophyton have not been described due to mature fruit previously lacking (Wurdack 1964, 1993). When originally described, T. merumense (Wurdack 1964) was reported as 4-locular and mature fruits were not known. With additional collections made afterwards, here we can report that the fruits of Tryssophyton merumense (Wurdack 5870 , US) are of the angular capsule type and 3-4 locular. The mature capsule is ca. $3 \mathrm{~mm}$ tall by $3-5 \mathrm{~mm}$ wide on a thickened, tapering pedicel (totalling $15-18 \mathrm{~mm}$ long with capsule plus poorly differentiated pedicel), obscurely angular with twice as many ridges as locules (e.g. 6-sided if 3-locular), lacks a central column and crowned by stiff valves and short calyx lobes (Figs 2I, 3G, H). The valves are two per carpel (6 or 8 total per capsule), cartilaginous, $1.5 \mathrm{~mm}$ tall, triangular and attached at the capsule periphery such that the interior edges (septicidal and loculicidal splits) are free to flex for dispersal of the $<20$ seeds loosely filling each locule. The fruit placenta remnants persist as basal-axillary clavate structures distally bearing fine fimbriae (Fig. 3G, H). Each fimbria is $0.2-0.4 \mathrm{~mm}$ long, terminated by a delicately attached seed and appears to consist of vasculature extending from the fruit placenta through a funiculus of uncertain length to the seed. At dehiscence, the erect fruit apex remains covered by the flexible valves.

Fruit and placenta morphology are remarkably diverse in Melastomataceae and phylogenetic evidence indicates complexity and homoplasy in fruit type evolution (Baumgratz 1983-1985, Clausing et al. 2000, Bacci et al. 2019). The broadly defined angular capsule fruit type, common in the Sonerileae-Dissochaeteae complex and many of its relatives, encompasses several distinct morphologies whose underlying developmental and structural differences are poorly understood. Tryssophyton presents its own fruit variant with the unusual features of basal-axile placentae, central column lacking and odd valves. Close relatives (i.e. Calvoa orientalis Taub., J. Wurdack 2853, US; Phainantha laxiflora (Triana) Gleason, Henkel 1689, US; Sarcopyramis napalensis, Henry $13562 c$, US) are mostly quite different, with axile placentae along a central column with 
seeds subsessile or on distinct short funiculi and fimbriae lacking. Boyania ayangannae (Henkel 147, US) has more similarity with basal-axile fruit placentae, central column lacking and fimbriae present (funiculi to $0.1 \mathrm{~mm}$, but fimbriae appearing longer due to frayed placental vasculature), although the overall fruit morphology differs in an apical glandular collar that lacks the stiff valves. In Bertolonia, the seeds are attached on long lateral placental branches of a usually distally-elaborated central column and have variable fimbriae that can be long (e.g. B. acuminata Gardner) or short to absent (e.g. B. maculata DC.) at dehiscence (see Baumgratz 1983-1985, 1989-1990). The long fimbriae - tips of a complex vascular skeleton - are also a combination of distally funicular and proximally placental origin and resemble those in Tryssophyton.

The seeds of Tryssophyton merumense are $0.6-0.7$ by $0.4-0.5 \mathrm{~mm}$, ovoid, lack appendages and are minutely papillose with sinuous interdigitating testa cell patterning (Fig. 4G). The seeds of T. quadrifolius appear similar (see Description), but were immature in one partly dissected young fruit. They fall within the variable "bertolonoid" type and most closely resemble the seeds of Triolena Naudin (Whiffin and Tomb 1972, Bacci et al. 2019: fig. 7).

\section{Acknowledgements}

We thank Alice Tangerini for the botanical illustration (Fig. 2), Stanley Yankowski for the leaf anatomy, John Clark for images of T. merumense (Fig. 3A-C), Aleks Radosavljevic for liquid preserved and DNA samples, the reviewers Frank Almeda and Renato Goldenberg for their helpful comments and NY and US for relevant collections. The laboratory work was conducted in and with the support of the Laboratories of Analytical Biology and Scanning Electron Microscopy Lab at the Smithsonian Institution and the Cullman Program for Molecular Systematics at The New York Botanical Garden. Partial support was provided by the National Science Foundation (DEB-1343612). This research was also partially funded by the generous support of Jayne and Leonard Abess of FAM. The Kamakusa Expedition was supported by a NGS/Waitt Grant (Karen Redden, PI) and the Smithsonian's Biological Diversity of the Guiana Shield Program (BDG). We also thank the other members of the 2012 Kamakusa Expedition including Aleks Radosavljevic, Karen Redden, Erin Tripp and the Amerindian team led by James Ralph.

\section{References}

Bacci LF, Michelangeli FA, Goldenberg R (2019) Revisiting the classification of Melastomataceae: Implications for habit and fruit evolution. Botanical Journal of the Linnean Society 190(1): 1-24. https://doi.org/10.1093/botlinnean/boz006

Baumgratz JFA (1983-1985) Morfologia dos frutos e sementes de Melastomatáceas Brasileiras. Arquivos do Jardim Botânico do Rio de Janeiro 27: 113-155. 
Baumgratz JFA (1989-1990) O gênero Bertolonia Raddi (Melastomataceae): revisão taxonômica e consideraçôs anatômicas. Arquivos do Jardim Botânico do Rio de Janeiro 30: 69-213. Berry PE, Gröger A, Holst BK, Morley T, Michelangeli FA, Luckana NG, Almeda F, Renner SS, Freire-Fierro A, Robinson OR, Yatskievych K (2001) Melastomataceae. In: Berry PE, Yatskievych K, Holst BK (Eds) Flora of the Venezuelan Guayana, Vol. 6 Liliaceae-Myrsinaceae. Missouri Botanical Garden Press, Saint Louis, Missouri, 263-528.

Clausing G, Renner SS (2001) Molecular phylogenetics of Melastomataceae and Memecylaceae: Implications for character evolution. American Journal of Botany 88(3): 486-498. https://doi.org/10.2307/2657114

Clausing G, Meyer K, Renner SS (2000) Correlations among fruit traits and evolution of different fruits within Melastomataceae. Botanical Journal of the Linnean Society 133(3): 303-326. https://doi.org/10.1111/j.1095-8339.2000.tb01548.x

Edgar RC (2004) MUSCLE: A multiple sequence alignment method with reduced time and space complexity. BMC Bioinformatics 5(1): 113. https://doi.org/10.1186/1471-2105-5-113

Figueiredo E (2001) A revision of Calvoa Hook.f. (Melastomataceae). Botanical Journal of the Linnean Society 136(2): 179-205. https://doi.org/10.1111/j.1095-8339.2001.tb00565.x

Funk V, Hollowell T, Berry P, Kelloff C, Alexander SN (2007) Checklist of the plants of the Guiana Shield (Venezuela: Amazonas, Bolivar, Delta Amacuro; Guyana, Surinam, French Guiana). Contributions from the United States National Herbarium 55: 1-584.

Gleason HA (1948) Melastomataceae. In: Maguire B \& collaborators (Eds) Plant explorations in Guiana in 1944, chiefly to the Tafelberg and the Kaieteur Plateau-V. Bulletin of the Torrey Botanical Club 75: 538-553. https://doi.org/10.2307/2485397

Goldenberg R, de Fraga CN, Fontana AP, Nicolas AM, Michelangeli FA (2012) Taxonomy and phylogeny of Merianthera (Melastomataceae). Taxon 61(5): 1040-1056. https://doi. org/10.1002/tax.615010

Goldenberg R, Almeda F, Sosa K, Ribeiro RC, Michelangeli FA (2015) Rupestrea: A new Brazilian genus of Melastomataceae, with anomalous seeds and dry indehiscent fruits. Systematic Botany 40(2): 561-571. https://doi.org/10.1600/036364415X688862

Hansen C (1978) A revision of the genus Sarcopyramis Wall. (Melastomataceae). Botanisk Tidsskrift 73(3-4): 177-183.

IUCN (2012) IUCN Red List Categories and Criteria: Version 3.1. Second edition. IUCN, Gland \& Cambridge, iv +32 pp.

IUCN (2019) Guidelines for Using the IUCN Red List Categories and Criteria. Version 14. Prepared by the Standards and Petitions Subcommitee. http://www.iucnredlist.org/documents/RedListGuidelines.pdf

Jacques-Félix H (1981) Révision du genre Calvoa (Melastomataceae). Bulletin du Muséum National d'Histoire Naturelle, Paris, 4e sér., 3, Sect. B. Adansonia 2: 123-143.

Kearse M, Moir R, Wilson A, Stones-Havas S, Cheung M, Sturrock S, Buxton S, Cooper A, Markowitz S, Duran C, Thierer T, Ashton B, Meintjes P, Drummond A (2012) Geneious Basic: An integrated and extendable desktop software platform for the organization and analysis of sequence data. Bioinformatics (Oxford, England) 28(12): 1647-1649. https:// doi.org/10.1093/bioinformatics/bts199 
Mendoza-Cifuentes H (2010) A new species of Boyania (Melastomataceae) in Colombia. Novon 20(4): 432-436. https://doi.org/10.3417/2008136

Michelangeli FA, Nicolas A, Morales-P ME, David H (2011) Phylogenetic relationships of Allomaieta, Alloneuron, Cyphostyla and Wurdastom (Melastomataceae), and the resurrection of the tribe Cyphostyleae. International Journal of Plant Sciences 172(9): 1165-1178. https://doi.org/10.1086/662032

Michelangeli FA, Guimaraes PJF, Penneys DS, Almeda F, Kriebel R (2013) Phylogenetic relationships and distribution of New World Melastomeae (Melastomataceae). Botanical Journal of the Linnean Society 171(1): 38-60. https://doi.org/10.1111/j.1095-8339.2012.01295.x

Michelangeli FA, Ulloa Ulloa C, Sosa K (2014) Quipuanthus, a new genus and species of Melastomataceae from the foothills of the Andes in Ecuador and Peru. Systematic Botany 39(2): 533-540. https://doi.org/10.1600/036364414X680924

Renner SS (1993) Phylogeny and classification of the Melastomataceae and Memecylaceae. Nordic Journal of Botany 13(5): 519-540. https://doi.org/10.1111/j.1756-1051.1993. tb00096.x

Renner SS, Clausing G, Meyer K (2001) Historical biogeography of Melastomataceae: The roles of tertiary migration and long-distance dispersal. American Journal of Botany 88(7): 1290-1300. https://doi.org/10.2307/3558340

Rocha MJR, Batista JAN, Guimaraes PJF, Michelangeli FA (2016) Phylogenetic relationships in the Marcetia alliance (Melastomeae, Melastomataceae) and implications for generic circumscription. Botanical Journal of the Linnean Society 181(4): 585-609. https://doi. org/10.1111/boj.12429

Rocha MJR, Guimaraes PJF, Michelangeli FA, Batista JAN (2018) Taxonomy of Marcetieae: A new neotropical tribe of Melastomataceae. International Journal of Plant Sciences 179(1): 50-74. https://doi.org/10.1086/694932

Stamatakis A (2014) RAxML version 8: A tool for phylogenetic analysis and post-analysis of large phylogenies. Bioinformatics (Oxford, England) 30(9): 1312-1313. https://doi. org/10.1093/bioinformatics/btu033

Ulloa Ulloa C, Neill DA (2006) Phainantha shuariorum (Melastomataceae), una especie nueva de la Cordillera del Cóndor, Ecuador, disyunta de un género Guayanés. Novon 16(2): 281-285. https://doi.org/10.3417/1055-3177(2006)16[281:PSMUEN]2.0.CO;2

Veranso-Libalah MC, Stone RD, Fongod AGN, Couvreur TLP, Kadereit G (2017) Phylogeny and systematics of African Melastomateae (Melastomataceae). Taxon 66(3): 584-614. https://doi.org/10.12705/663.5

Whiffin T, Tomb AS (1972) The systematic significance of seed morphology in the neotropical capsular-fruited Melastomataceae. American Journal of Botany 59(4): 411-422. https:// doi.org/10.1002/j.1537-2197.1972.tb10112.x

Wurdack JJ (1964) Melastomataceae. In: Maguire B, Wurdack J and Collaborators (Eds) The botany of the Guayana Highland-Part V. Memoirs of the New York Botanical Garden 10: $135-186$.

Wurdack JJ (1986) Atlas of hairs for neotropical Melastomataceae. Smithsonian Contributions to Botany 63(63): 1-80. https://doi.org/10.5479/si.0081024X.63 
Wurdack JJ (1993) Melastomataceae-Melastomatoideae. In: Görts-van Rijn ARA (Ed.) Flora of the Guianas, Series A: Phanerogams, Fasc.13. Koeltz Scientific Books, Köenigstein, Germany, 3-301.

Wurdack KJ (2017) A new tiny-leaved species of Raveniopsis (Rutaceae) from the Pakaraima Mountains of Guyana. PhytoKeys 91: 1-12. https://doi.org/10.3897/phytokeys.91.14763

Wurdack K, Tripp E, Radosavljevic A, Redden K (2013) Kamakusa Expedition 2012: First botanical exploration of a remote Guyana tepui. The Plant Press 16(1), n.s.: 8-10. https:// nmnh.typepad.com/files/vol16no1.pdf

Zeng SJ, Zou LH, Wang P, Hong WJ, Zhang GQ, Chen LJ, Zhuang XY (2016) Preliminary phylogeny of Fordiophyton (Melastomataceae), with the description of two new species. Phytotaxa 247(1): 45-61. https://doi.org/10.11646/phytotaxa.247.1.3

Zhou QJ, Lin CW, Dai JH, Zhou RC, Liu Y (2019a) Exploring the generic delimitation of Phyllagathis and Bredia (Melastomataceae): A combined nuclear and chloroplast DNA analysis. Journal of Systematics and Evolution 57(3): 256-267. https://doi.org/10.1111/jse.12451

Zhou QJ, Dai JH, Lin CW, Denda T, Zhou RC, Liu Y (2019b) Recircumscription of Bredia and resurrection of Tashiroea (Sonerileae, Melastomataceae) with description of a new species T. villosa. PhytoKeys 127: 121-150. https://doi.org/10.3897/phytokeys.127.36608

\section{Appendix I}

Sources for plastid data used in the phylogenetic analysis of Tryssophyton. Ordered as: Taxon, Voucher (new data only), GenBank numbers for $n d h F, r b c L$ and $r p l 16$, respectively. Dash (-) indicates missing data, asterisk $\left(^{*}\right)$ indicates taxa that presently appear under a synonym in GenBank and bold indicates new data.

Outgroups: Alzatea verticillata Ruiz \& Pav., AF215591, -, AY151598. Eugenia uniflora L., AF215592, AF294255, AF215627. Myrtus communis L., AF215593, AF294254, AF215628. Olinia ventosa (L.) Cufod., AF215594, AF215546, -. Penaea mucronata L., AF270756, AJ605090, AF222782. Rhynchocalyx lawsonioides Oliv., AF270757, AF215547, AF215631. Melastomataceae: Aciotis purpurascens (Aubl.) Triana, AF215561, -, AF322231. Allomaieta ebejicosana Lozano, JF831961, JF831986, JF832012. Allomaieta grandiflora Gleason, JF831962, JF831987, JF832013. Allomaieta hirsuta (Gleason) Lozano, JF831963, JF831988, JF832014. Allomaieta pancurana Lozano, JF831967, JF831993, JF832017. Allomaieta villosa (Gleason) Lozano, JF831969, JF831994, JF832019. Allomaieta zenufanasana Lozano, JF831970, JF831995, JF832020. Alloneuron ulei Pilg., JF831971, JF831996, JF832021. Arthrostemma ciliatum Pav. ex D.Don, AF215562, AF215522, AF215605. Astronia smilacifolia Triana ex C.B.Clarke, AF215549, -, AF215596. "Behuria comosa R. Tavares, Baumgratz \& R.Goldenb.”, JQ899111, JQ899084, JQ899060. Behuria glutinosa Cogn., JQ899112, JQ899085, JQ899061. Bellucia aequiloba Pilg., JF831972, JF831997, JF831997. Bellucia arborescens (Aubl.) Baill.*, EU711377, JQ626318, JF832035. Bellucia grossularioides (L.) Triana, EU711372, EU711385, JF832023. 
Bellucia mespiloides (Miq.) J.F.Macbr.*, GU968822, KF781623, -. Bellucia pentamera Naudin, AF215578, KF781624, AF215615. Bellucia spruceana (Benth. ex Triana) J.F.Macbr.*, GU968823, KF781625, -. Bertolonia margaritacea Naudin*, JQ899130, AF215512, JQ899080. Bertolonia mosenii Cogn., JF831973, JF831998, JF832024. Blakea gracilis Hemsl., JF831974, JF831999, JF832025. Blakea multiflora D.Don*, JQ899132, JQ899107, JQ899082. Blakea schlimii (Naudin) Triana, EU711373, EU711386, JF832026. Blakea trinervia L., AF215555, AF215516, AF215600. Blakea watsonii (Cogn.) Penneys \& Almeda, JQ899133, JQ899108, JQ899083. Blastus borneensis Cogn. ex Boerl., AF215585, -, AF215621. Blastus cochinchinensis Lour., KX066244, KP094575, KM521849. Blastus pauciflorus (Benth.) Guillaumin, KX066245, KP095022, KM521850. Boyania colombiana Humberto Mend., -, JQ899086, JQ899062. Brasilianthus carajensis Almeda \& Michelang., KX765168, KX765169, KX765170. Bredia fordii (Hance) Diels, KT354883, KT354892, KM521851. Bredia sessilifolia H.L.Li, -, KP094838, -. Calvoa grandifolia Cogn., -, AY667151, AY660632. Cambessedesia eichleri Cogn., JQ899113, JQ899087, JQ899063. Cambessedesia espora (A.St.Hil. ex Bonpl.) DC., JQ899114, JQ899088, JQ899064. Cambessedesia hilariana (A.St.Hil. ex Bonpl.) DC., JQ899115, JQ899089, JQ899065. Cambessedesia membranacea Gardner, AY553782, -, AY553775. Castratella piloselloides (Bonpl.) Naudin, AY553783, AY553779, AY553774. Centradenia inaequilateralis (Schltdl. \& Cham.) G.Don, AF215563, EU711387, AF215606. Chalybea macrocarpa (Uribe) Penneys \& Morales-P, JQ899121, JQ899095, JQ899071. Comolia microphylla Benth., JF831975, JF832000, JF832028. Desmoscelis villosa (Aubl.) Naudin, EU711374, EU711389, JF832029. Dichaetanthera arborea Baker, AF272800, -, AF294470. Dichaetanthera asperrima Cogn., AF215564, AF215523, AF215607. Diplectria divaricata (Willd.) O.Ktze, AF215556, AF270746, AF215601. Dissochaeta bracteata (Jack) Blume, AF289369, -, AF294471. Dolichouraspiritusanctensis Brade, JQ899116, JQ899090, JQ899066. Driessenia glanduligera Stapf, AF215586, AF270749, AF215622. Eriocnema fulva Naudin, AY553781, AY553777, AY553772. Fordiophyton brevicaule C.Chen, KT354884, KT354893, KM521852. Fordiophyton chenii S.Jin Zeng \& X.Y.Zhuang, KT354886, KT354895, KM521854. Fordiophyton cordifolium C.Y.Wu ex C.Chen, KT354885, KT354894, KM521853. Fordiophyton faberi Stapf, KU208089, KU208090, KM521855. Fordiophyton huizhouense S.Jin Zeng \& X.Y.Zhuang, KT354887, KT354896, KM521856. Fordiophyton peperomiifolium (Oliv.) C.Hansen, KT354888, KT354897, KM521857. Fordiophyton zhuangiae S.Jin Zeng \& G.D.Tang, KX066246, -, KX037425. Graffenrieda latifolia (Naudin) Triana, AM235411, AM235644, AM235447. Graffenrieda moritziana Triana, EU055944, EU711390, JF832031. Graffenrieda rotundifolia (Bonpl.) DC., AF215576, AF215532, AF215613. Henriettea martiusii (DC.) Naudin, EU711375, EU711391, JF832032. Henriettea patrisiana DC., JF831977, JF832002, JF832033. Henriettea ramiflora (Sw.) DC., GU968811, KF781627, -. Henriettea succosa (Aubl.) DC., GU968815, KF781628, -. Henriettea tuberculosa (Donn. Sm.) L.O.Williams*, GU968816, KF781629, -. Heterocentron elegans (Schltdl.) Kuntze, AF272804, AY456135, AF325926 Heterocentron subtriplinervium (Link \& Otto) A.Braun \& 
C.D.Bouché, AF215566, AF270747, AF210374. Heterotis fruticosa (Brenan) VeransoLibalah \& G.Kadereit, AF272802, -, AF210377. Heterotis rotundifolia (Sm.) Jacq.Fél., AF215565, U26323, AF270745. Huberia consimilis Baumgratz, JQ899117, JQ899091, JQ899067. Huberia peruviana Cogn., JQ899118, JQ899092, JQ899068. Lavoisiera cordata Cogn., AF215582, AF215540, AF210371. Lavoisiera pulchella Cham., EU711376, EU711392, JF832034. Macairea radula (Bonpl.) DC., EU711378, EU711394, JF832036. Macrocentrum cristatum (DC.) Triana, AM235412, AM235645, AM235448. Macrocentrum repens (Gleason) Wurdack, AF215551, AF215513, AF215598. Medinilla alternifolia Blume, AF289374, -, AF322229. Medinilla humbertiana H. Perrier, AF215557, AF215517, AF215602. Melastoma beccarianum Cogn., AF272805, AM235646, AM235449. Melastoma candidum D.Don, AB436365, GQ436728, AF215608. Melastoma dodecandrum Lour., AF272808, GQ436727, -. Melastoma malabathricum L., AF272810, AF270748, AB436376. Melastoma sanguineum Sims, AF270754, HQ415218, AB436378. Melastoma tetramerum Hayata, AB436364, -, AB436373. Memecylon durum Cogn., AM235408, AM235641, AM235444. Memecylon edule Roxb., AF215574, AF215528, AF215609. Meriania macrophylla (Benth.) Triana, AM235414, AM235647, AM235450. Meriania nobilis Triana, AF215577, AF215533, AF215614. Meriania phlomoides (Triana) Almeda, EU055971, EU711395, JF832037. "Merianthera bullata R.Goldenb., Fraga \& A.P.Fontana”, JQ899129, JQ899104, JQ899078. Merianthera burlemarxii Wurdack, JQ899122, JQ899096, JQ899072. "Merianthera parvifolia R.Goldenb., Fraga \& A.P.Fontana”, JQ899127, JQ899102, JQ899077. Merianthera pulchra Kuhlm., JQ899124, JQ899098, JQ899073. Merianthera sipolisii (Glaz. \& Cogn.) Wurdack, JQ899126, JQ899100, JQ899075. "Merianthera verrucosa R.Goldenb., Fraga \& A.P.Fontana”, JQ899125, JQ899099, JQ899074. Miconia bicolor (Mill.) Triana*, EU056130, KX397981, -. Miconia calycina Cogn., EU056001, JF832003, JF832038. Miconia cubatanensis Hoehne, EU056020, -, -. Miconia dodecandra (Desr.) Cogn., EU056026, EU711396, JF832039. Miconia donaeana Naudin, AM235415, AM235648, AM235451. Miconia fasciculata Gardner, EU056033, -, -. Miconia mayeta (D. Don.) Michelang.*, AF215581, AF215537, AF215618. Miconia petiolaris (Schltdl. \& Cham.) Michelang., AM235410, AM235643, AM235446. Miconia rubra (Aubl.) Mabb.*, AF215579, AF215535, AF215616. Miconia secunmexicana G.Ocampo \& Almeda*, AF215580, AF215536, AF215617. Miconia tococa (Desr.) Michelang.*, AM235417, AM235650, -. Miconia urbani (Cogn.) Cogn.*, AF270753, AF215538, AF215619. Monochaetum calcaratum (DC.) Triana, AF215568, AF215524, AF210372. Monolena primuliflora Hook. f., AF215552, AF215514, AF270743. Mouriri crassifolia Sagot, -, FJ038111, -. Mouriri guianensis Aubl., AF215575, AF215529, AF215610. Mouriri helleri Britton, AF322230, AF270752, AF215611. Nepsera aquatica (Aubl.) Naudin, AF215569, JQ592692, AF210373. Osbeckia chinensis L., AF215570, AF215525, AF210378. Osbeckia stellata Buch.-Ham. ex Ker Gawl., AF272818, U26330, -. Oxyspora paniculata (D.Don) DC.*, KX527089, MH722293. Phainantha laxiflora (Triana) Gleason, JF831980, JF832006, JF832043. Phainantha shuariorum C.Ulloa \& D.A.Neill, 
JF831981, JF832007, JF832044. Phyllagathis gymnantha Korth., AF215590, -, AF215626. Phyllagathis hispidissima (C.Chen) C.Chen, KT354889, KT354899, KM521858. Physeterostemon fiaschii R.Goldenb. \& Amorim, EU711379, EU711397, JF832045. Physeterostemon jardimii R.Goldenb. \& Amorim, EU711381, EU711399, JF832046. "Physeterostemon thomasii Amorim, Michelangeli \& R.Goldenb.", EU711383, EU711401, JF832047. Pternandra coerulescens Jack, AF215558, AF215518, AF322232. Pternandra echinata Jack, AF215559, AF215520, AF270744. Pternandra multiflora Cogn., AF215560, -, AF215603. Pterolepis glomerata (Rottb.) Miq., AF215571, AF215526, AF210376. Rhexia mariana L., AF272819, KJ773817, AF323723. Rhexia virginica L., AF215587, MG248427, AF215623. Rhynchanthera grandiflora(Aubl.) DC.,AF215584,AF215542,AF210369. "Rupestreajohnwurdackiana (Baumgratz \& D’El Rei Souza) Michelang., Almeda, \& R.Goldenb.”, KM373899, KM373900, KM373901. Salpinga maranonensis Wurdack, JF831982, JF832008, JF832048. Salpinga secunda Schrank \& Mart. ex DC., EU711384, EU711402, JF832049. Sarcopyramis parvifolia Merr. ex H.L.Li, -, KX527237, -. Siphanthera paludosa (DC.) Cogn., -, AY553780, AY553776. Tibouchina grossa (L.f.) Cogn., JF831983, JF832009, JF832050. Tibouchina longifolia (Vahl) Baill., AF215572, JQ592704, AF210375. Tibouchina urvilleana (DC.) Cogn., AF272820, U26339, AF322234. Tigridiopalma magnifica C.Chen, KT354891, KT354900, KM521859. Triolena amazonica (Pilg.) Wurdack, JF831984, JF832010, JF832051. Triolena paleacea (Triana) Almeda \& Alvear, JF831976, JF832001, JF832030. Triolena pustulata Triana*, JQ899135, JQ899110, AF215599. Tristemma littorale Benth., -, AY667150, AY660631. Tristemma mauritianum J.F.Gmel., AF272821, -, AF322233. Tryssophyton merumense Wurdack, A. Radosavljevic 165 (US), MK284234, MK284232, -. Tryssophyton quadrifolius K.Wurdack \& Michelang., K. Wurdack 5865 (US), -, MK284233, -. Warneckea membranifolia (Hook. f.) Jacq.-Fél., AF331711, KC628335, -. Wurdastom cuatrecasasii (Wurdack) B.Walln., JF831985, JF832011, -. 